\title{
Molecular characterization of human Trypanosoma cruzi isolates from endemic areas in Panama
}

\author{
O ctavio E Sousa/ ${ }^{+}$, Franklyn Samudio* , Corina de Juncá, José E Calzada*
}

\author{
Center for Research and Diagnosis of Parasitic Diseases, Faculty of Medicine, University of Panama, Panama *Instituto \\ Conmemorativo Gorgas de Estudios de la Salud, Panama, Panama
}

The present work provides information on Trypanosoma cruzi genotype circulating in endemic areas of Chagas disease in Panama. A total of 26 crude stocks of T. cruzi, isolated from the blood of persons with different clinical profiles of Chagas disease were collected and crio-conserved until used. Most of the stocks had been characterized by means of isoenzyme electrophoresis on cellulose acetate membranes. The clinical profiles of infected persons included $9(34.6 \%)$ asymptomatic and 17 acute (65.4\%) including 5 (19.2\%) fatal cases, 2 under 5 years old and 3 adults. A multiplex-PCR assay based on the amplification of the non-transcribed spacer of the mini-exon gene was performed. All stocks of T. cruzi included in the study were found to correspond to Tc I group. This result supports the predominance of T. cruzi-I in the transmission cycles affecting the human population in the Republic of Panama.

Key words: Trypanosoma cruzi - lineage - acute Chagas disease - Panama

Trypanosoma cruzi is a blood parasite of man in America, often resulting in clinical manifestations and pathologies of Chagas disease. It is generally accepted that some 18 million people have been demonstrated to be infected by this parasite. Chagas disease, first described by Carlos Chagas in 1909 from endemic areas of Brazil, is naturally recognized as a zoonosis that affects the human population of endemic areas of Latin America, from Argentina and Chile in the south, to Mexico and Southern United States in the north. Transmission of the parasite results from contamination with the infective trypanosomes found in the feces of naturally infected triatomine vectors that exist in sylvatic, rural or domiciliary habitats. Chagas disease has been recorded in the Republic of Panama since 1930, when trypomastigotes of T. cruzi were found in the blood of three hospitalized children suspected of malarial fever. A report of these cases was published by Miller (1931). Chagas disease, in Panama, is more frequently reported from rural areas on both sides of the Panama Canal (Sousa \& Johnson 1971). In these areas, the parasite is primarily transmitted by Rhodnius pallescens, a triatomine vector found in close association with the palm-tree (Attalea butyracea) in domestic, peridomiciliary, and sylvatic ecotopes (Whitlaw $\&$ Chaniotis 1978). The infection in man can result in asymptomatic, clinical, and severe, at times fatal disease. However, when symptomatic the disease in Panama generally runs a milder course than in $T$. cruzi infections acquired in endemic areas of the Southern Cone of America (Nuñez 1966). In Panama the infection is primarily of the cardiotropic form during the acute and chronic phases

Financial partial support: grant PAN 6010, International Atomic Energy Agency

Corresponding author: osousa@ancon.up.ac.pa .

Received 5 January 2006

Accepted 9 May 2006 with no evidence of the digestive form developing during later stages of the infection. Since the early pathological studies there is no evidence of chagasic megasyndromes (Blandon et al. 1969). The situation appears to be similar to that of Venezuela (Añez et al. 2004), Amazonia, Brazil (Coura et al. 1999), and part of Central America (RuizSanchez et al. 2005).

Studies on the genetic variability of $T$. cruzi have recently demonstrated two primary phylogenetic lineages, Tc-I and Tc-II, with a third group of hybrid strains still under revision. Further studies identified and supported six T. cruzi lineages (Brisse et al. 2000) including T.cruzi-I and T.cruzi-II. The high polymorphism of T. cruzi and the significance of its genetic variability in the pathogenesis of Chagas disease has been considered (Macedo et al. 2004) and led to establish the basis for a clonal-histotropic model for Chagas disease (Macedo et al. 2002). Geographical distribution and epidemiological considerations such as natural sources of infections, vectors and reservoirs, have been studied resulting in several suggested associations (Miles et al. 2005, Yeo et al. 2005). T. cruzi-I, appears associated with American marsupials, Didelphis spp., arboreal ecologies and northern distribution, while T. cruzi-II are more associated with armadillos, terrestrial ecologies and Southern-Cone areas in America.

The parasites analyzed were obtained from the blood of patients during the acute phase of the disease; people with parasitaemia demonstrated through hemoculture and/ or xenodiagnosis, including asymptomatic, clinical, and fatal cases. This study provides information on the genotype of $T$. cruzi affecting man in this area, in an effort to establish their relationship to the different groups known.

A total of 26 crude stocks of T. cruzi, isolated from the blood of patients with different clinical profiles of Chagas disease were collected and maintained in liquid nitrogen. Most of the stocks had been characterized by means of isoenzyme electrophoresis on cellulose acetate membranes as previously described (Kreutzer \& Sousa 1981). Information regarding the case, identification of the stock, location, and year of isolation is presented in the Table. 
Parasites were grown in liver infusion tryptose medium (LIT) supplemented with $10 \%$ bovine fetal serum until logarithmic phase was reached. Parasites were collected by centrifugation $\left(2500 \mathrm{~g}\right.$ at $4^{\circ} \mathrm{C}$ for $\left.10 \mathrm{~min}\right)$ and washed twice with buffer PBS (pH 7.2). The pellet was used for DNA extraction using a commercial kit following manufacturer' instructions (Wizard Genomic DNA Purification System, Promega, US). DNA integrity was checked in $1 \%$ agarose gels and DNA concentration estimated by spectrophotometry at $260 \mathrm{~nm}$. A multiplex-PCR assay based on the amplification of the non-transcribed spacer of the miniexon gene (Fernandez et al. 2001) was performed on the Panamanian T. cruzi stocks using $25 \mathrm{ng}$ of DNA. The results are summarized in the Table, including CL-Brener and Y strains as Tc-II controls, as well as a local T. rangeli isolate from Panama. All stocks of T. cruzi included in the study amplified a $200 \mathrm{bp}$ product which corresponds to group 1 (Figure). No evidence of TcII was found. The clinical profiles of infected patients included $9(34.6 \%)$ asymptomatic, and 17 acute (65.4\%) including 5 (19.2\%) fatal cases, 2 under 5 years and 3 adults. It has been our experience that in this area it is extremely difficult to isolate parasites through blood culture or serial xenodiagnosis during the chronic stage of Chagas disease (Sousa 1988). Six patients included in the present work were periodically examined during a prolonged period (11 to 23 years) after the initial parasitemia without evidence of parasites through blood cultures or xenodiagnosis but, remaining seropositive against $T$. cruzi.
In Panama there appears to exist a single lineage involved in the epidemiological factors of transmission in the rural endemic area of Chagas disease. T. cruzi-I predominates in this cycle involving $R$. pallescens as vector, the palm-tree A. butyracea the ecotope, and Didelphis marsupialis as primary reservoir. The present work is fur-

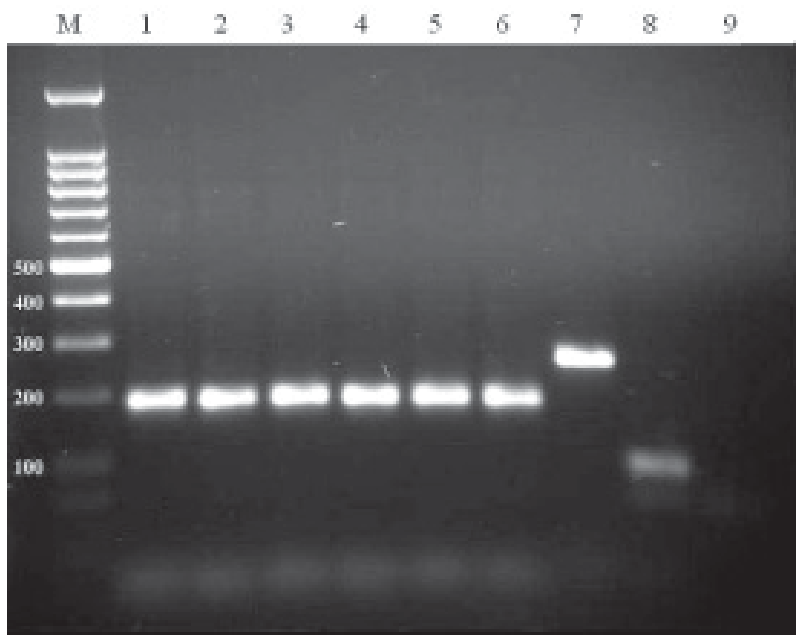

Molecular characterization of Trypanosoma cruzi human isolate through the amplification of the non-transcribed spacer of the mini-exon gene. M: molecular marker, 100 bp ladder; Lanes - 1-5: T. cruzi Panamanian human isolates; 6: Tc-I control; 7: Tc-II control; 8: T. rangeli control; 9: blank.

TABLE

Characterization of Trypanosoma cruzi isolates from acute chagasic persons in Panama, Panama

\begin{tabular}{|c|c|c|c|c|c|c|c|c|}
\hline \multirow{2}{*}{$\begin{array}{l}\text { Case } \\
\text { No. }\end{array}$} & \multirow{2}{*}{$\begin{array}{l}\text { Isolate } \\
\text { ID }\end{array}$} & \multirow{2}{*}{$\begin{array}{l}\text { Age } \\
\text { yrs }\end{array}$} & \multirow[t]{2}{*}{ Locality } & \multirow{2}{*}{$\begin{array}{l}\text { Clinical } \\
\text { profile }\end{array}$} & \multirow[t]{2}{*}{ Outcome } & \multicolumn{2}{|c|}{ Parasitology } & \multirow[t]{2}{*}{ Lineage } \\
\hline & & & & & & $\mathrm{C}$ & $\mathrm{X}$ & \\
\hline 1 & MHOM/PA/80/JDM & 1 & Santa Rita & Acute & Chronic & + & + & 1 \\
\hline 2 & MHOM/PA/83/DA & 78 & Aguas Claras & Asymptomatic & Indetermined & + & + & 1 \\
\hline 3 & MHOM/PA/81/IYM & 7 & Mendoza & Asymptomatic & Indetermined & - & + & 1 \\
\hline 4 & MHOM/PA/78/LEM & 6 & Burunga & Acute & Chronic & + & + & 1 \\
\hline 5 & MHOM/PA/71/JRO & 29 & Chilibre & Acute & ND & + & + & 1 \\
\hline 6 & MHOM/PA/65/MJR & 30 & Bique & Acute & Chronic & + & + & 1 \\
\hline 7 & MHOM/PA/81/MG & 28 & Chepo & Asymptomatic & Chronic & - & + & 1 \\
\hline 8 & MHOM/PA/77/JZ & 33 & Arraijan & Acute & Fatal & + & + & 1 \\
\hline 9 & MHOM/PA/65/RA & 29 & Chepo & Asymptomatic & Chronic & - & + & 1 \\
\hline 10 & MHOM/PA/80/MA & 19 & Buena Vista & Acute & Chronic & + & + & 1 \\
\hline 11 & MHOM/PA/87/IR & 42 & Capira & Acute & Indetermined & - & + & 1 \\
\hline 12 & MHOM/PA/70/AC & 17 & Mendoza & Asymptomatic & Indetermined & - & + & 1 \\
\hline 13 & MHOM/PA/71MEB & 1 & Altos del Jobo & Acute & Chronic & + & + & 1 \\
\hline 14 & MHOM/PA/79/HO & 18 & Cerro Cama & Asymptomatic & ND & - & + & 1 \\
\hline 15 & MHOM/PA/89/PG & 1 & Arraijan & Acute & Indetermined & + & ND & 1 \\
\hline 16 & MHOM/PA/72/LCF & 35 & La Chorrera & Asymptomatic & Chronic & - & + & 1 \\
\hline 17 & MHOM/PA/91/CGT & 22 & Chilibre & Acute & Fatal & + & + & 1 \\
\hline 18 & MHOM/PA/95/MM & 3 & Bayano & Acute & Fatal & + & + & 1 \\
\hline 19 & MHOM/PA/95YP & 13 & Pacora & Asymptomatic & Indetermined & + & ND & 1 \\
\hline 20 & MHOM/PA/00/FC & 26 & Tocumen & Acute & Fatal & - & + & 1 \\
\hline 21 & MHOM/PA/02/PM & 31 & Burunga & Acute & ND & + & + & 1 \\
\hline 22 & MHOM/PA/74/ER & 2 & Capira & Acute & Fatal & + & + & 1 \\
\hline 23 & MHOM/PA/73/SV & 1 & Arraijan & Acute & Chronic & + & + & 1 \\
\hline 24 & MHOM/PA/70/AH & 5 & Cerro Cama & Asymptomatic & Indetermined & + & + & 1 \\
\hline 25 & MHOM/PA/83MFC & 45 & Bajo Grande & Acute & Chronic & - & + & 1 \\
\hline 26 & MHOM/PA/80/DM & 3 & Capira & Acute & Chronic & + & + & 1 \\
\hline
\end{tabular}

C: blood culture; $\mathrm{X}$ : xenodiagnosis; ND: not determined 
ther supported by studies on $60 \mathrm{~T}$. cruzi stocks found in naturally infected $R$. pallescens collected in 30 royal palm trees (A. butyracea) from three different localities from endemic areas of Chagas disease in Panama (data not shown) as well as parasites obtained from the blood of a domestic dog and one common opossum (D. marsupialis). All stocks tested have been characterized as T. cruzi-I. It is not yet clear whether clonal T. cruzi-II may be present in reservoir hosts or vectors other than $R$. pallescens. The situation in this country is similar to that described for the Amazon region of Brasil (Coura et al.1999), Colombia (Cuervo et al. 2002), Venezuela (Añez et al. 2004), and Guatemala and Mexico (Ruiz-Sanchez et al. 2005) where $T$. cruzi-I predominates among the parasites recovered from endemic areas of the disease. This condition contrasts with the asumption that Chagas disease is due to a single parasite lineage, $T$. cruzi II and argues against human infection cases exclusively due to T. cruzi I strains (Di Noia et al. 2002).

\section{REFERENCES}

Añez N, Crisante G, da Silva FM, Rijas A, Carrasco H, Umezawa ES, Stolf AM, Ramírez JL, Teixeira MMG 2004. Predominance of lineage I among Trypanosoma cruzi isolates from Venezuelan patients with different clinical profiles of acute Chagas disease. Trop Med Interna Health 9: 1319-1326.

Blandon R, Guevara JF, Johnson CM 1969. Tránsito esofágico en pacientes con enfermedad de Chagas en Panamá. Arq Gastroenterol 6: 189-197.

Brisse S, Dujardin JC, Tibayrenc M 2000. Identification of six Trypanosoma cruzi lineages by sequence-characterised amplified region markers. Mol Biochem Parasitol 111: 95-105.

Coura JR, Junqueira ACV, Boia MN, Fernandez O 1999. Chagas disease: from bush to huts and houses. Is it the case of the Brazilian Amazon? Mem Inst Oswaldo Cruz 94: 379-384.

Cuervo P, Cupolillo E, Segura I, Saravia N, Fernandez O 2002. Genetic diversity of Colombian sylvatic Trypanosoma cruzi isolates revealed by DNA. Mem Inst Oswaldo Cruz 97: 877-880.

Di Noia JM, Buscaglia CA, De Marchi CR, Almeida IC, Frasch CC 2002. A Trypanosoma cruzi small surface molecule provides the first immunological evidence that Chagas disease is due to a single parasite lineage. J Exp Med 195: 401-413.

Fernandez O, Santos SS, Cupolillo E, Mendonca B, Derre R, Junqueira ACV, Santos IC, Sturm NR, Naiff RD, Barret Campbell DA, Coura JR 2001. A mini-exon polymerase chaín reaction to distinguísh the major groups of Trypanosoma cruzi and $T$. rangeli in the Brazilian Amazon. Trans $R$ Trop Med Hyg 95: 97-99.
Kreutzer RD, Sousa OE 1981. Biochemical characterization of Trypanosoma spp. By isozyme electrophoresis. Am J Trop Med Hyg 30: 308-317.

Macedo AM, Oliveira RP, Pena SDJ 2002. Chagas Disease: Role of Parasite Genetic Variation in Pathogenesis, Expert Reviews Mol Med, Cambridge University Press, p. 1-15.

Macedo AM, Machado CR, Oliveira RP, Pena SDJ 2004. Trypanosoma cruzi: genetic structure of populations and relevance of genetic variability to the pathogenesis of Chagas disease. Mem Inst Oswaldo Cruz 99: 1-12.

Miles MA, Feliciangeli MD, Rojas de AA 2005. American trypanosomiasis (Chagas disease) and the role of molecular epidemiology in guiding control strategies. BMJ 326: 14441448.

Miller JN 1931. Chagas disease in Panama: report of three cases. South Med J 26: 645.

Nuñez JM 1966. Enfermedad de Chagas: datos pertinentes y revisión de casos atendidos en el Hospital Santo Tomás 1955 a 1964. Arch Méd Panameños XV:35-47.

Ruiz-Sánchez R, de León MP, Matta V, Reyes PA Lopez R, Jay D, Monteón VM 2005. Trypanosoma cruzi isolates from Mexican and Guatemalan acute and chronic chagasic cardiopathy patients belong to Trypanosoma cruzi I. Mem Inst Oswaldo Cruz 100: 281-283.

Sousa OE 1988. Relationship between vector species and their vectorial capacity for certain strains of Trypanosoma cruzi. Rev Argentina Microbiol 20 (Supl.): 63-70.

Sousa OE, Johnson CM 1971. Frequency and distribution of Trypanosoma cruzi and Trypanosoma rangeli in the Republic of Panama. Am J Trop Med Hyg 20: 405-410.

Souto RP, Fernandez O, Macedo AM, Campbell DA, Zingales B 1996. DNA markers define two major phylogenetic lineages of Trypanosoma cruzi. Mol Bioch Parasitol 83: 141152.

Whitlaw JT, Chaniotis BM 1978. Palm trees and Chagas disease in Panama. Am J Trop Med Hyg 27: 873-881.

Yeo M, Acosta N, Llewellyn M, Sánchez H, Adamson S, Miles GAJ, López E, González N, Patterson JS, Gaunt MW, Rojas de Arias A, Miles MA 2005. Origins of Chagas disease: Didelphis species are natural hosts of Trypanosoma cruzi I and armadillos hosts of Trypanosoma cruzi II, including hybrids. Int J Parasitol 35: 225-233.

Zingales B, Stolf BS, Souto RP, Fernandez O, Briones MRS 1999. Epidemiology, biochemistry and evolution of Trypanosoma cruzi lineages based on ribosomal RNA sequences. Mem Inst Oswaldo Cruz 94 (Suppl. 1): 159-164. 